\section{Production Temperatures Influence Growth and Physiology of Leatherleaf Fern}

\section{Robert H. Stamps}

Central Florida Research and Education Center-Apopka, Institute of Food and Agricultural Sciences, University of Florida, 2807 Bin ion Road, Apopka, FL 32703

\section{Terril A. Nell and James E. Barrett \\ Environmental Horticulture Department, Institute of Food and Agricultural Sciences, University of Florida, Gainesville, FL 32611}

Additional index words. Rumohra adiantiformis, photosynthesis, transpiration, carbohydrates, dark respiration

Abstract. Leatherleaf fern [Rumohra adiantiformis (Forst.) Ching] fronds produced under a high-temperature regime (HTR, 30 day/25C night) grew faster and produced sori earlier than those in a low-temperature regime (LTR, 20 day/15C night). Abaxial diffusive conductance was lower for HTR-grown fronds. Light-saturated net $\mathrm{CO}_{2}$ assimilation rates (Pn) and dark respiration were lower for HTR fronds, but light-saturated Pn efficiencies (chlorophyll basis); light compensation points; and soluble sugars, starch, and nonstructural carbohydrate levels were similar for the two regimes. Transpiration and water-use efficiency (mass basis) at light saturation were similar for fronds from both temperature treatments. Comparison of physiological characteristics of fronds from the two temperature regimes revealed no differences that might account for reduced postharvest longevity of fronds produced at the higher temperatures.
Leatherleaf fern is the cut foliage most frequently used in floral arrangements in the United States (Robertson et al., 1983) and accounts for $\approx 60 \%$ of wholesale sales of U.S. cut cultivated greens production [U.S. Dept. of Agriculture (USDA), 1993]. Most of the world's production of leatherleaf fern occurs in Florida where it is grown under $60 \%$ to $80 \%$ light exclusion provided by polypropylene shade fabric or oak trees. Ambient temperatures vary greatly in Florida's major production areas, with daily means ranging from $\approx 13$ to 28C (National Climatic Data Center, 1991). Data on the effects of production temperature on leatherleaf fern are extremely limited and deal mainly with seasonal effects on fronds' subsequent vase life (Mathur et al., 1982; Poole et al., 1984). These studies show a strong association between frond development during the summer and rapid postharvest destion temperatures were controlled (Stamps et al., 1989), fronds produced at high (35 day/ 24C night) temperatures exhibited postharvest desiccation, whereas fronds produced at lower temperatures did not. This inability to maintain water balance has been called fern

Received for publication 17 Mar. 1993, Accepted for publication 5 Aug. 1993. Florida Agricultural Experiment Stations journal series no. R-03267. We greatly appreciate the technical assistance of Deborah Gaw Wallace and Loretta Satterthwaite. The cost of publishing this paper was defrayed in part by the payment of page charges. Under postal regulations, this paper therefore must be hereby marked advertisement solely to indicate this fact. iccation. In a postharvest study where produc- wilt and frond curl syndrome (Nell et al., 1983). Temperature also has been shown to affect net $\mathrm{CO}_{2}$ assimilation (net photosynthesis, Pn) and dark respiration of leatherleaf fern fronds. Mathur and Bhagsari (1983) found that $\mathrm{Pn}$ was higher and dark respiration was lower at $20 \mathrm{C}$ than at 30 or $40 \mathrm{C}$; however, all the fronds used in their tests were produced under the same conditions. Our experiment was conducted to study the effects of production temperatures on the development and physiology of leatherleaf fern fronds of similar chronological ages and to look for differences that might be related to postharvest longevity.

\section{Materials and Methods}

Vigorous leatherleaf fern plants growing in 2.5-liter plastic pots were repotted into 11.2-liter pots containing a 1 peat: 1 sand: 1 perlite (by volume) mix amended with $5.6 \mathrm{~kg}$ dolomite, $2.9 \mathrm{~kg}$ superphosphate, and $1.8 \mathrm{~kg}$ of a micronutrient blend (PERK; Estech General Chemical Corp., Chicago) per cubic meter. A total of 20 pots, 10 for each temperature regime, were placed in controlled-environment chambers (CEL 512-37; Sherer-Gillett, Marshall, Mich.) set for a 12-h day/night cycle of 20/15C (low-temperature regime, LTR) or 30/25C (high-temperature regime, HTR). The day/night temperature fluctuations were kept the same $(5 \mathrm{C})$ for both regimes because the amplitude of temperature variation in controlled environments has been shown to affect plant development and physiology (Chabot and Lewis, 1975). Day/night relative humidities were $75 \% / 80 \% \pm 10 \%$ and $65 \% / 75 \% \pm$ $15 \%$ for the LTR and HTR chambers, respectively. These relative humidities and temperatures are similar to those found in the major Florida production area during March and July, respectively. Lighting in each chamber consisted of eight 2.4-m cool-white fluorescent lamps (Lifeline F96T12/CW/VHO; Sylvania Lighting Products Group, GTE Products Corp., Danvers, Mass.) and four 60-W incandescent bulbs for a photosynthetic pho-

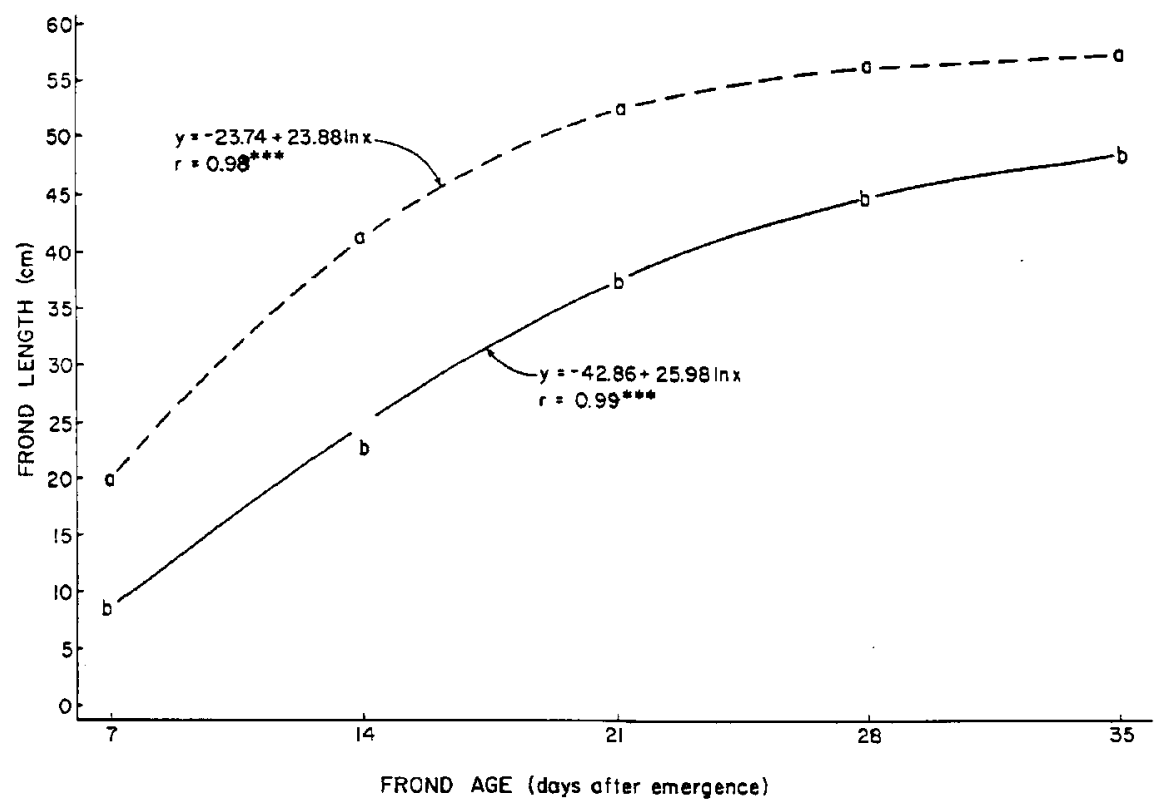

Fig. 1. Effect of day/night production temperatures in controlled-environment chambers on growth of leatherleaf fern fronds. Letters represent means of 10 replications, and different letters indicate significant differences for t test comparisons at $P \leq 0.01$ within days for treatments. Grown at a lowtemperature treatment of 20 day/15C night (-) or a high-temperature treatment of 30 day/ $25 \mathrm{C}$ night (---). ***Significant at $P \leq 0.001$. 
ton flux (PPF) $36 \mathrm{~cm}$ above the top of the pot (approximate canopy midpoint) of 120 $\mu \mathrm{mol} \cdot \mathrm{m}^{-2} \cdot \mathrm{s}^{-1}$ as measured with a quantum radiometer (LI-185A; LI-COR, Lincoln, Neb.) at the beginning and end of the growth cycle. The total watt input provided by incandescent lamps was kept in the $10 \%$ to $20 \%$ range recommended by Cathey and Campbell ( 1980). Indi-
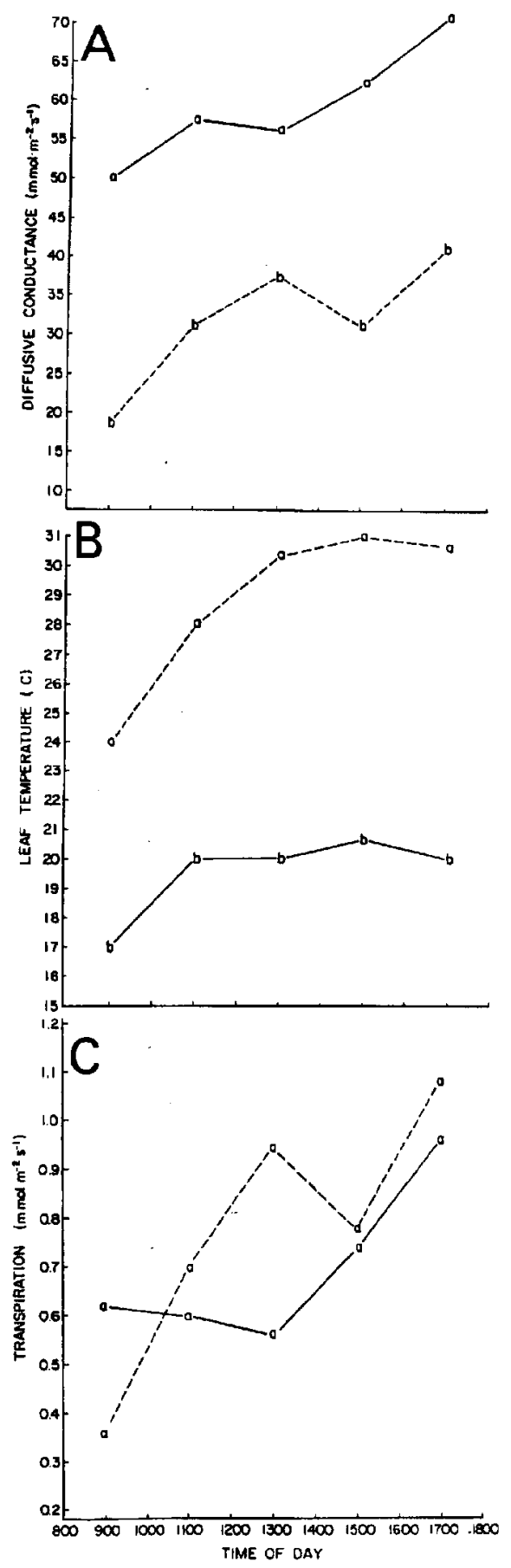

Fig. 2. (A) Abaxial diffusive conductance, (B) leaf temperatures, and $(\mathrm{C})$ transpiration of leatherleaf fern fronds growing in controlled-environment chambers under day/night cycles of a lowtemperature treatment of 20 day/15C night (-) or a high-temperature treatment of 30 day/25C night (----). Letters represent means of six replications, and different letters indicate significant differences for $t$ test comparisons at $\mathrm{P} \leq 0.02$ within time of day for treatments. vidual fronds from these temperature treatments were the experimental units. Plants were watered daily and fertilized weekly with 1 liter of complete liquid fertilizer made by using a $20 \mathrm{~N}-4.4 \mathrm{P}-16.6 \mathrm{~K}$ water-soluble fertilizer (Peters Florida Special; Grace-Sierra, Milpitas, Calif.). Due to the higher water loss from the HTR pots and resulting higher irrigation volumes, concentrations of 400 and $500 \mathrm{ppm} \mathrm{N}$ were used for LTR and HTR, respectively. These fertilization rates maintained conductivity readings and $\mathrm{pHs}$ for all pots between $0.4-0.6$ and $5.5-5.9 \mathrm{dS} \cdot \mathrm{m}^{-1}$, respectively, as determined using a 2 water: 1 medium (v/v) extract procedure. Saucers placed under each pot served as water reservoirs to prevent soil moisture availability from becoming a limiting factor between waterings. Two weeks after experiment initiation, fronds that were just beginning to emerge (bud stage) were tagged. Same-age fronds were used because frond age may influence frond variability (Marousky, 1983; Poole et al., 1984).

Lengths of tagged fronds, two fronds per pot, were measured at weekly intervals. Dates when fronds first developed son visible to the unaided eye were recorded. An infrared gas analyzer (AR-600R; Anarad, Santa Barbara, Calif.) in an open system was used to measure net $\mathrm{CO}_{2}$ and water vapor fluxes of individual mature leatherleaf fern fronds. Light was supplied from a fixture equipped with a 400-W high-pressure sodium vapor lamp that was allowed to warm up to full output $(\approx 30 \mathrm{~min})$ before any readings were recorded. Light compensation points were determined by reducing intensities using layers of cheesecloth until the net $\mathrm{CO}_{2}$ flux was zero. Net $\mathrm{CO}_{2}$ fluxes were measured at up to 20 light levels $\left(3.4-673 \mu \mathrm{mol} \cdot \mathrm{m}^{-2} \cdot \mathrm{s}^{-1}\right)$ per plant. Dark respiration was measured when the recorder (model 9 176; Varian Aerograph, Walnut Creek, Calif.) reached a stable read- ing after the lamp and room lights were turned off. Leaf temperatures were maintained at 30.5 $\pm 1.5 \mathrm{C}$, which represents the average daily temperatures during the months when vase life is most reduced (Stamps et al., 1989). Yadav et al. (1978) have found that 30C is the optimum for net photosynthesis and dark respiration of eight fern species in India. Air flow rates through the chamber were 4 liters. $\min ^{-1}$ at higher light levels and $\mathrm{Pn}$ rates, and they were 2 liters. $\mathrm{min}^{-1}$ under reduced $\mathrm{Pn}$ rates. Ambient $\mathrm{CO}_{2}$ concentrations ranged from 315 to $345 \mu \mathrm{mol} \cdot \mathrm{mnol}^{-1}$. Transpiration (E), measured during the Pn determinations, was ascertained using the previously mentioned system. The order of running Pn determinations was randomized over treatments to eliminate bias due to possible hysteresis or biological rhythms (Fails et al., 1982). Pn determinations were made for-one replication per day. Plants were thoroughly watered the day before and again the day readings were made.

Chlorophyll determinations were made using a modification of Amen's (1949) procedures. Two $0.27-\mathrm{cm}^{2}$ leaf disks, obtained using a cork borer, were punched from pinnules of each frond used for Pn measurements. The disks were quartered using a razor blade and placed in $5 \mathrm{ml}$ of acidified $(10 \% \mathrm{HCl})$ methanol. Dark extraction was for $48 \mathrm{~h}$ at-15C. Optical density (OD) was measured at $652 \mathrm{~nm}$ using a spectrophotometer (Spectronic 7 10; Bausch\& Lomb, Rochester, N.Y.). Optical density was converted to milligrams per liter using Amen's formula and corrected for sample size.

Diffusive conductance, transpiration, and pinnule temperatures were measured in the growth chambers using a steady-state pyrometer (LI-1600M; LI-COR) with $1.0-\mathrm{cm}^{2}$ aperture. Adaxial transpiration was $\approx 10 \%$ of total transpiration during the day (data not shown), so only abaxial readings were recorded. Measurements were made on dark-green, mature, nonsporulating fronds at a terminal pinnule of the central pinna.

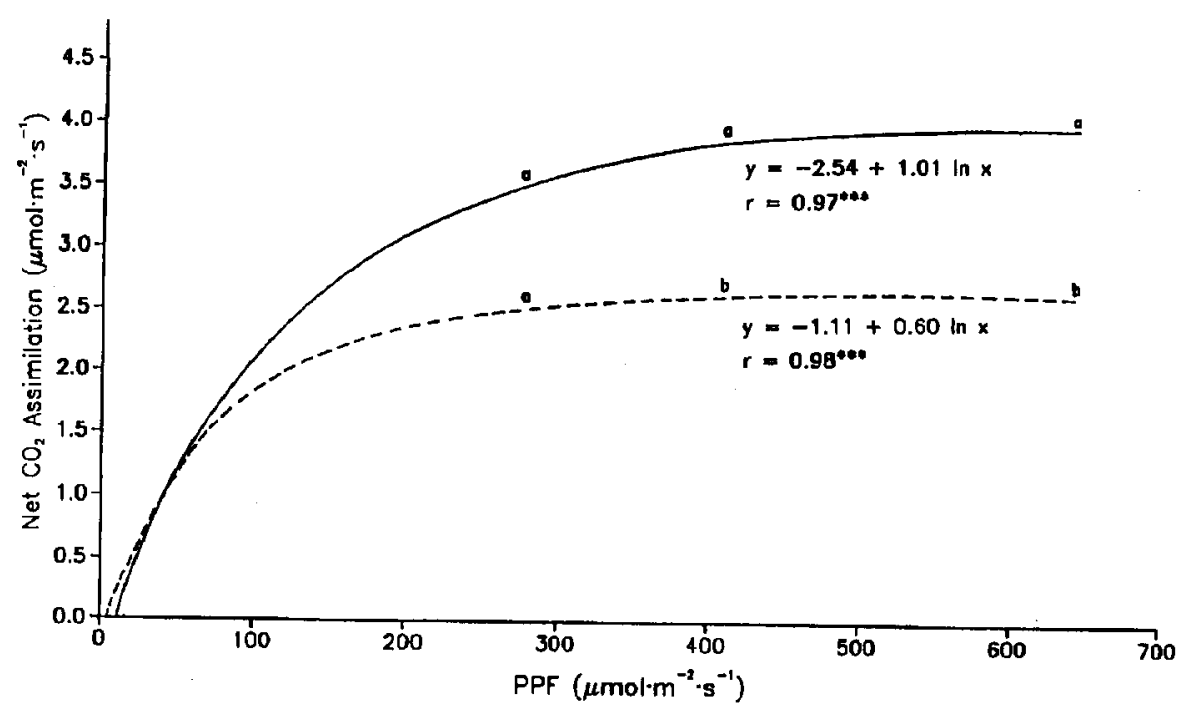

Fig. 3. Effect of photosynthetic photon flux (PPF) on net $\mathrm{CO}_{2}$ assimilation of leatherleaf fern fronds grown at a low-temperature treatment of 20 day/15C night $(-)$ or a high-temperature treatment of 30 day/ $25 \mathrm{C}$ night (---) and measured at 30C. Letters represent means of 10 replications, and different letters indicate significant differences for $t$ test comparisons at $P \leq 0.05$ within PPF for treatments. "'Significant at $\mathrm{P} \leq 0.001$. 
Table 1. Physiological characteristics for leatherleaf fern fronds grown under low- or high-temperature regimes (LTR; HTR).

\begin{tabular}{|c|c|c|c|}
\hline \multirow{2}{*}{$\begin{array}{l}\text { Physiological } \\
\text { characteristics }\end{array}$} & \multicolumn{2}{|c|}{$\begin{array}{c}\text { Day/night production temp }{ }^{2} \\
\left({ }^{\circ} \mathrm{C}\right)\end{array}$} & \multirow{2}{*}{$\begin{array}{c}\text { Significance } \\
\text { level }^{y}\end{array}$} \\
\hline & $20 / 15$ & $30 / 25$ & \\
\hline $\begin{array}{l}\text { Light-saturated net } \mathrm{CO}_{2} \text { assimilation } \\
\text { (Pn) }\left(\mu \mathrm{mol} \mathrm{CO}_{2} / \mathrm{m}^{2} \text { per sec) }\right.\end{array}$ & $4.05 \pm 0.49^{\mathrm{x}}$ & $2.68 \pm 0.32$ & 0.030 \\
\hline Chlorophyll (chl) $\left(\mathrm{mg} \cdot \mathrm{dm}^{-2}\right)$ & $6.91 \pm 0.48$ & $5.20 \pm 0.21$ & 0.007 \\
\hline $\begin{array}{l}\text { Light-saturated Pn efficiency } \\
\text { (chlorophyll basis) }\end{array}$ & & & \\
\hline 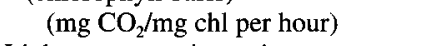 & $0.92 \pm 0.08$ & $0.81 \pm 0.08$ & 0.343 \\
\hline $\begin{array}{l}\text { Light compensation point } \\
\left(\mu \mathrm{mol} \cdot \mathrm{m}^{-2} \cdot \mathrm{s}^{-1}\right)\end{array}$ & $13.0 \pm 2.6$ & $7.4 \pm 2.1$ & 0.114 \\
\hline $\begin{array}{l}\text { Dark respiration at } 30 \mathrm{C} \\
\left(\mu \mathrm{mol} \mathrm{CO} / \mathrm{m}^{2} \text { per sec }\right)\end{array}$ & $0.32 \pm 0.08$ & $0.11 \pm 0.02$ & 0.022 \\
\hline Soluble sugars (mg $\cdot \mathrm{g}^{-1}$ dry wt) & $208 \pm 25$ & $191 \pm 17$ & 0.583 \\
\hline Starch $\left(\mathrm{mg}^{-1} \mathrm{~g}^{-1}\right.$ dry wt) & $34.3 \pm 6.2$ & $35.1 \pm 2.6$ & 0.910 \\
\hline $\begin{array}{l}\text { Nonstructural carbohydrates } \\
\left(\mathrm{mg} \cdot \mathrm{g}^{-1} \text { dry wt }\right)\end{array}$ & $242 \pm 27$ & $226 \pm 18$ & 0.631 \\
\hline $\begin{array}{l}\text { Transpiration (at light saturation) } \\
\left(\mathrm{mmol} \mathrm{H}_{2} \mathrm{O} / \mathrm{m}^{2} \text { per sec) }\right.\end{array}$ & $1.172 \pm 0.166$ & $0.836 \pm 0.084$ & 0.088 \\
\hline $\begin{array}{l}\text { Water-use efficiency } \\
\left(\mu \mathrm{mol} \mathrm{CO}{ }_{2}: \text { mmol H}_{2} \mathrm{O}\right)\end{array}$ & $4.0 \pm 0.7$ & $3.6 \pm 0.6$ & 0.661 \\
\hline
\end{tabular}

y Significance based on $t$ test.

${ }^{\mathrm{x}}$ Means of 10 replications $\pm \mathrm{SE}$.

Fronds used for Pn determinations were freeze-dried at $-40 \mathrm{C}$ and $4 \mathrm{~Pa}$ immediately after $\mathrm{Pn}$ and surface areas were measured. Freeze-drying lasted $\geq 72 \mathrm{~h}$; then tissue was stored in a desiccator at $-15 \mathrm{C}$. Tissue was ground through a 20 -mesh screen, and a 50$\mathrm{mg}$ sample was boiled in $10 \mathrm{ml}$ of $80 \%$ ethanol and centrifuged at $7410 \times \mathrm{g}$ for $1 \mathrm{~h}$. One-half milliliter of supernatant was diluted with 9.5 $\mathrm{ml}$ deionized water for soluble sugar determinations. The centrifuged pellet was combined with $5 \mathrm{ml}$ of enzyme solution ( $40 \mathrm{ml}$ of $20 \mathrm{mM}$ phosphate buffer $+20 \mathrm{mg} \alpha$-amylase $+20 \mathrm{mg}$ amyloglucosidase $+17.6 \mathrm{mg} \mathrm{CaCl}_{2}$ ) and incubated for $12 \mathrm{~h}$ at $34 \mathrm{C}$ using a constant-temperature bath. The sample was centrifuged as previously mentioned, and $0.5 \mathrm{ml}$ of supernatant was diluted with $9.5 \mathrm{ml}$ of deionized water. The sugar content of the sample was determined using a phenol-sulfuric acid assay. One-half milliliter of $5 \%$ phenol and 2.5 $\mathrm{ml}$ of concentrated $\mathrm{H}_{2} \mathrm{SO}_{4}$ were added to $0.5 \mathrm{ml}$ of each diluted sample and allowed to cool; then optical density was measured at $490 \mathrm{~nm}$ using a spectrophotometer. Standards were prepared using D-glucose and deionized water.

\section{Results and Discussion}

Growth of fronds was faster at HTR than at LTR (Fig. 1). Poole et al. (1984) found that, in shadehouses, fronds emerging during warmer months also grew more rapidly. Both HTR and LTR growth curves were logarithmic. However, early growth of fronds was faster (Fig. 1) and sori developed sooner under HTR conditions. Sori were visible on $53 \%$. of the HTR fronds but on none of the LTR fronds 4 weeks after emergence; however, percentages of fronds with visible sori were the same on HTR- and LTR-grown fronds at 5 weeks after emergence. Increased growth and development rate due to higher production temperatures have been reported for many crops (Ballantine and Forde, 1970; Blackman, 1956;
Friend, 1975; Gertsson, 1984; Moe, 1972; Woledge and Jewiss, 1969).

Abaxial diffusive conductance of water vapor $\left(\mathrm{g}_{\mathrm{wv}}\right)$ and leaf temperatures increased during the light period (Fig. 2 A and B). Both measurements were different for fronds at the two temperature regimes throughout the day cycle, with HTR fronds having reduced $g_{w v}$ compared to LTR fronds throughout the day. The leaf-to-air vapor pressure gradient (VPG) was $\approx 2.5$ times greater in HTR due to the higher temperatures and lower relative humidities; therefore, reduced $\mathrm{g}_{\mathrm{wv}}$ would be of adaptive advantage in reducing water loss. In between treatments in spite of the lower VPG fact, there were no transpiration differences under the LTR regime (Fig. 2C). Abaxial diffusive conductance of LTR fronds were low for crops, and measured values for both LTR and HTR were similar to those of many trees (Nobel, 1983), many of which are also hypostomatous. Diffusive conductance for fronds at both regimes were similar to those for two epiphytic crassulacean acid metabolism ferns (Wong and Hew, 1976) and lower than those previously reported for field-grown leatherleaf fern fronds (Nell et al., 1983). The differences in leatherleaf-fern leaf diffusive conductance may have been due to the lower light levels in the controlled-environment chambers compared to those in the field.

Pn measured at 30C was logarithmic, and Pn for fronds grown at the two temperature regimes differed at PPFs $\geq 430 \mu \mathrm{mol} \cdot \mathrm{m}^{-2} \cdot \mathrm{s}^{-1}$ (Fig. 3). As Mathur and Bhagsari (1983) reported, light saturation at $30 \mathrm{C}$ occurred at $\approx 500 \mu \mathrm{molŽm} \mathrm{m}^{2} \mathrm{~s}^{-1}$ for shadehouse-grown leatherleaf fern. Pn under LTR at light saturation was similar to that previously reported by Mathur and Bhagsari (1983) for leatherleaf fern grown in a shadehouse and held in a greenhouse with a 30C daily mean. At saturation, Pn for HTR fronds was 34\% lower than for LTR ones (Table 1). Despite higher Pn at light saturation for LTR-produced fronds, lightsaturated Pn efficiencies determined on a chlorophyll basis were the same for LTR and HTR fronds because the chlorophyll content was lower in HTR than in LTR fronds (Table 1). The lack of differences in efficiencies suggests that there were no qualitative biochemical differences in photosynthesis due to production temperatures. Light compensation points were low and statistically similar for both groups, but dark respiration rates were lower for HTR fronds (Table 1). Concentrations of soluble sugars, starch, and nonstructural carbohydrate were similar for both tempera-

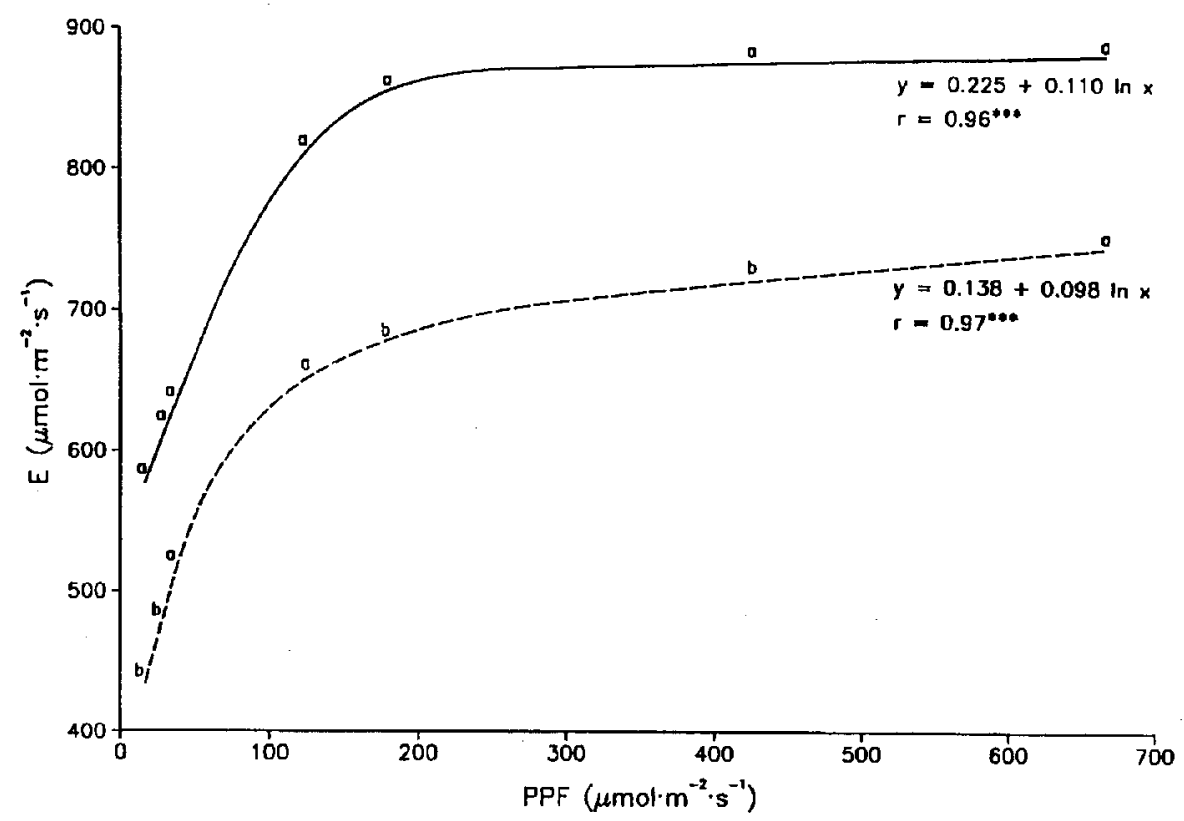

Fig. 4. Effect of photosynthetic photon flux (PPF) at 30C on transpiration of leatherleaf fern fronds grown at a low-temperature treatment of 20 day/15C night (-)or a high-temperature treatment of 30 day/ 25C night (----). Letters represent means of six replications, and different letters indicate significant differences for $t$ test comparisons at $P \leq 0.04$ within PPF for treatments. *** Significant at $\mathrm{P} \leq 0.001$. 
ture treatments; therefore, substrate availability does not seem to be responsible for the differences in dark respiration rates. The reduced dark respiration rates for HTR fronds may be due to increased (physiological) aging of HTR fronds compared to LTR fronds because of more rapid development at the higher production temperatures (Geronimo and Beevers, 1964). Dark respiration decreases with aging (Bozarth et al., 1982; Geronimo and Beevers, 1964; Wager, 1941). E curves were logarithmic in relation to PPF (Fig. 4) and similar in shape and orientation to those for Pn (Fig. 3). E was lower $(\mathrm{P}<0.05)$ for HTR fronds than for LTR fronds at PPF levels between 183 and 431 and $<32 \mu \mathrm{mol} \cdot \mathrm{m}^{-2} \cdot \mathrm{s}^{-1}$. The ability of stomata to open, as measured by the size of the stomatal aperture, decreases as leaves age (Fisher, 1967). If the HTR fronds were physiologically significantly older, reduced stomatal conductance could be responsible for reduced E. The stomata of HTR fronds also may have been conditioned to lower conductivity. E and water-use efficiency (mass basis) at light saturation were similar for fronds from both temperature regimes (Table 1).

Leaf characteristics related to the potential for reduced postharvest longevity-relatively low carbohydrate reserves, high dark respiration rates, and high abaxial leaf diffusive conductance of water vapor-were not found in HTR-produced fronds. In fact, the lower dark respiration rate and the lower leaf diffusive conductance would be expected to increase, rather than decrease, vase life. These physiological measurements do not indicate why leatherleaf fern fronds produced at higher summer temperatures have reduced vase life compared to those produced during cooler weather. Further research is needed to determine the effects, if any, of temperature on the anatomy and cuticle characteristics of leatherleaf fern fronds that might influence vase life.

\section{Literature Cited}

Amen, D.I. 1949. Copper enzymes in isolated chloroplasts. Polyphenoloxidase in Beta vulgaris. Plant Physiol. 24:1-15.

Ballantine, J.E.M. and B.J. Forde. 1970. The effect of light intensity and temperature on plant growth. Amer. J. Bet. 57: 1150-1 159.

Blackman, G.E. 1956. Influence of light and temperature on leaf growth, p. 151-169. In: FL. Milthorpe (cd.). The growth of leaves. Butterworth, London.

Bozarth, C. S., R.A. Kennedy, and K.A. Schekel, 1982. The effects of leaf age on photosynthesis in rose. J. Amer. Soc. Hort. Sci. 107:707-712.

Cathey, H.M. and L.E. Campbell. 1980. Light and lighting systems for horticultural plants, p. 491537. In: J. Janick (ed,). Horticultural review. vol. 2. AVI, Westport, Corm.

Chabot, B.F. and A.R. Lewis. 1975. Thermal acclimation of photosynthesis in northern red oak. Photosynthetic 10:130-135,

Fails, B. S., A.J, Lewis, and J.A. Barden. 1982. Net photosynthesis and transpiration of sun- and shade-grown Ficus benjamina leaves, J. Amer. Soc. Hort. Sci. 107:758-761.

Fisher, R.A. 1967. Stomatal physiology with particular reference to the after-effect of water stress and to behavior in epidermal strips. $\mathrm{PhD}$ Diss., Univ. of California, Davis.

Friend, D.J.C. 1975. Adaptation and adjustment of photosynthetic characteristics of gametophytes and sporophytes of Hawaiian tree-fern (Cibotium glaucum) grown at different irradiances. Photosynthetic 9:157-164.

Geronimo, J. and H. Beevers. 1964. Effects of aging and temperature on respiratory metabolism of green leaves. Plant Physiol. 39:786-793.

Gertsson, U.E. 1984. Effect of temperature, daylength and light intensity on growth and development of Dipladenia sanderi Hemsl. 'Rosea'. Scientia Hort, 22:287-293.

Marousky, F.J. 1983. Premature wilt of leatherleaf fern with different pinnae maturity from various growing environments. Proc. Fla. State Hort. Soc. 96:270-271.

Mathur, D.D. and A.S. Bhagsari. 1983. Effect of photosynthetically active radiation, temperature, and antitranspirants on photosynthesis and respiration of leatherleaf fern. HortScience 18: 189191.

Mathur, D. D., R.H. Stamps, and C.A. Conover. 1982. Postharvest wilt and yellowing of leatherleaf fern. Proc. Fla. State Hort. Soc. 95: 142143.

Moe, R. 1972, Effect of daylength, light intensity and temperature on growth and flowering in roses. J. Amer. Soc. Hort. Sci. 97:796-800.

National Climatic Data Center. 1991. Local climatological data, annual summary with comparative data, Daytona Beach, Fla. Natl. Climatic Ctr., Asheville, N.C.

Nell, T, A., J.A. Barrett, and R.H. Stamps. 1983. Water relations and frond curl of cut leatherleaf fem. J. Amer. Soc., Hort. Sci. 108:516-519.

Nobel, P.S. 1983. Biophysical plant physiology and ecology. W.H. Freeman and Co., San Francisco.

Poole, R, T., C.A. Conover, and R.H. Stamps. 1984. Vase life of leatherleaf fern harvested at various times of the year and at various frond ages. Proc. Fla. State Hort. Soc. 97:266-269.

Robertson, J. L., L. Chatfield, and T. Prince. 1983. All about foliage. Flor. Rev. 172: 18-22.

Stamps, R, H., T.A, Nell, and D.J. Cantliffe. 1989. Production temperature affects leatherleaf fern postharvest desiccation. HortScience 24:325327.

U.S. Dept. of Agriculture. 1993. Floriculture crops, 1992 summary. U.S. Dept. Agr., Natl. Agr. Stat. Serv., Agr. Stat. Board, Washington, D.C.

Wager, H.G. 1941. On the respiration and carbon assimilation rates of some arctic plants as related to temperature. New Phytol. 40: 1-19.

Woledge, J. and O.R. Jewiss. 1969. The effect of temperature during growth on the subsequent rate of photosynthesis in leaves of tall fescue (Festuca arundinacea Schreb.). Ann. Bet. 33:897-913

Wong, S.C. and C.S. Hew. 1976. Diffusive resistance, titratable acidity, and $\mathrm{CO}_{2}$ fixation in two tropical epiphytic ferns. Amer. Fern J. 66:121123.

Yadav, A. K., P. Sharma, and T.N. Bhardwaja. 1978. Photosynthesis and respiration of some Rajasthan ferns. Geobios 5: 185-187. 
ton flux (PPF) $36 \mathrm{~cm}$ above the top of the pot (approximate canopy midpoint) of 120 $\mu \mathrm{mol} \cdot \mathrm{m}^{-2} \cdot \mathrm{s}^{-1}$ as measured with a quantum radiometer (LI-185A; LI-COR, Lincoln, Neb.) at the beginning and end of the growth cycle. The total watt input provided by incandescent lamps was kept in the $10 \%$ to $20 \%$ range recommended by Cathey and Campbell ( 1980). Indi-
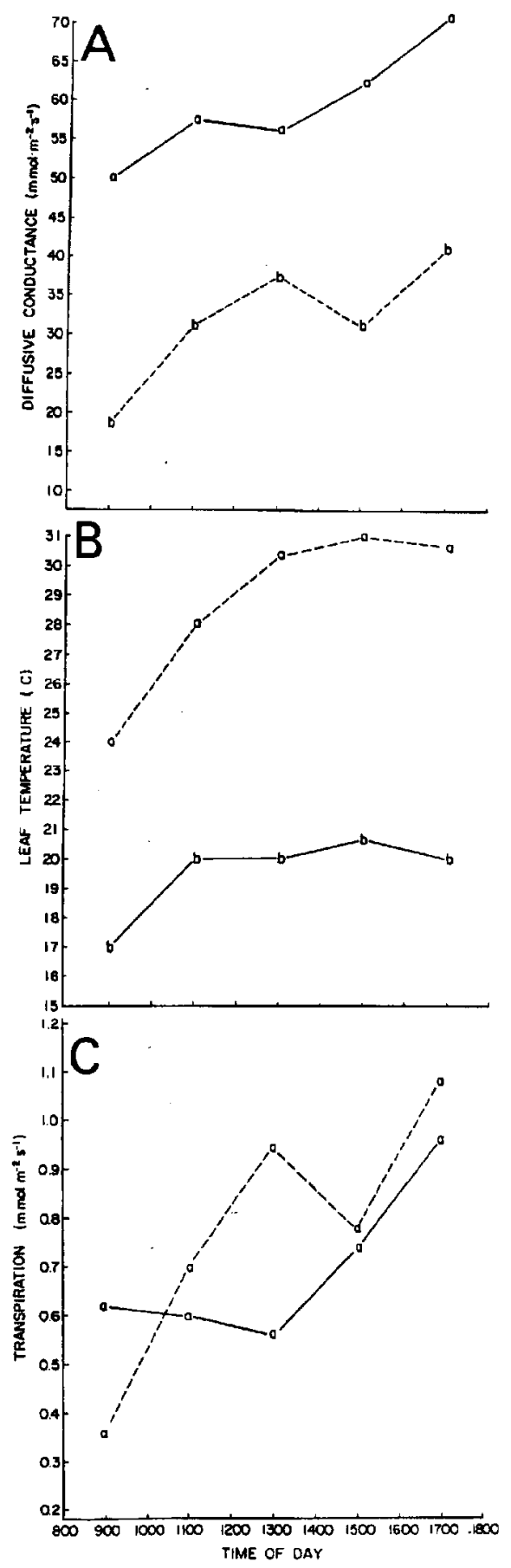

Fig. 2. (A) Abaxial diffusive conductance, (B) leaf temperatures, and $(\mathrm{C})$ transpiration of leatherleaf fern fronds growing in controlled-environment chambers under day/night cycles of a lowtemperature treatment of 20 day/15C night (-) or a high-temperature treatment of 30 day/25C night (----). Letters represent means of six replications, and different letters indicate significant differences for $t$ test comparisons at $\mathrm{P} \leq 0.02$ within time of day for treatments. vidual fronds from these temperature treatments were the experimental units. Plants were watered daily and fertilized weekly with 1 liter of complete liquid fertilizer made by using a $20 \mathrm{~N}-4.4 \mathrm{P}-16.6 \mathrm{~K}$ water-soluble fertilizer (Peters Florida Special; Grace-Sierra, Milpitas, Calif.). Due to the higher water loss from the HTR pots and resulting higher irrigation volumes, concentrations of 400 and $500 \mathrm{ppm} \mathrm{N}$ were used for LTR and HTR, respectively. These fertilization rates maintained conductivity readings and $\mathrm{pHs}$ for all pots between $0.4-0.6$ and $5.5-5.9 \mathrm{dS} \cdot \mathrm{m}^{-1}$, respectively, as determined using a 2 water: 1 medium (v/v) extract procedure. Saucers placed under each pot served as water reservoirs to prevent soil moisture availability from becoming a limiting factor between waterings. Two weeks after experiment initiation, fronds that were just beginning to emerge (bud stage) were tagged. Same-age fronds were used because frond age may influence frond variability (Marousky, 1983; Poole et al., 1984).

Lengths of tagged fronds, two fronds per pot, were measured at weekly intervals. Dates when fronds first developed son visible to the unaided eye were recorded. An infrared gas analyzer (AR-600R; Anarad, Santa Barbara, Calif.) in an open system was used to measure net $\mathrm{CO}_{2}$ and water vapor fluxes of individual mature leatherleaf fern fronds. Light was supplied from a fixture equipped with a 400-W high-pressure sodium vapor lamp that was allowed to warm up to full output $(\approx 30 \mathrm{~min})$ before any readings were recorded. Light compensation points were determined by reducing intensities using layers of cheesecloth until the net $\mathrm{CO}_{2}$ flux was zero. Net $\mathrm{CO}_{2}$ fluxes were measured at up to 20 light levels $\left(3.4-673 \mu \mathrm{mol} \cdot \mathrm{m}^{-2} \cdot \mathrm{s}^{-1}\right)$ per plant. Dark respiration was measured when the recorder (model 9 176; Varian Aerograph, Walnut Creek, Calif.) reached a stable read- ing after the lamp and room lights were turned off. Leaf temperatures were maintained at 30.5 $\pm 1.5 \mathrm{C}$, which represents the average daily temperatures during the months when vase life is most reduced (Stamps et al., 1989). Yadav et al. (1978) have found that 30C is the optimum for net photosynthesis and dark respiration of eight fern species in India. Air flow rates through the chamber were 4 liters. $\min ^{-1}$ at higher light levels and $\mathrm{Pn}$ rates, and they were 2 liters. $\mathrm{min}^{-1}$ under reduced $\mathrm{Pn}$ rates. Ambient $\mathrm{CO}_{2}$ concentrations ranged from 315 to $345 \mu \mathrm{mol} \cdot \mathrm{mnol}^{-1}$. Transpiration (E), measured during the Pn determinations, was ascertained using the previously mentioned system. The order of running Pn determinations was randomized over treatments to eliminate bias due to possible hysteresis or biological rhythms (Fails et al., 1982). Pn determinations were made for-one replication per day. Plants were thoroughly watered the day before and again the day readings were made.

Chlorophyll determinations were made using a modification of Amen's (1949) procedures. Two $0.27-\mathrm{cm}^{2}$ leaf disks, obtained using a cork borer, were punched from pinnules of each frond used for Pn measurements. The disks were quartered using a razor blade and placed in $5 \mathrm{ml}$ of acidified $(10 \% \mathrm{HCl})$ methanol. Dark extraction was for $48 \mathrm{~h}$ at-15C. Optical density (OD) was measured at $652 \mathrm{~nm}$ using a spectrophotometer (Spectronic 7 10; Bausch\& Lomb, Rochester, N.Y.). Optical density was converted to milligrams per liter using Amen's formula and corrected for sample size.

Diffusive conductance, transpiration, and pinnule temperatures were measured in the growth chambers using a steady-state pyrometer (LI-1600M; LI-COR) with $1.0-\mathrm{cm}^{2}$ aperture. Adaxial transpiration was $\approx 10 \%$ of total transpiration during the day (data not shown), so only abaxial readings were recorded. Measurements were made on dark-green, mature, nonsporulating fronds at a terminal pinnule of the central pinna.

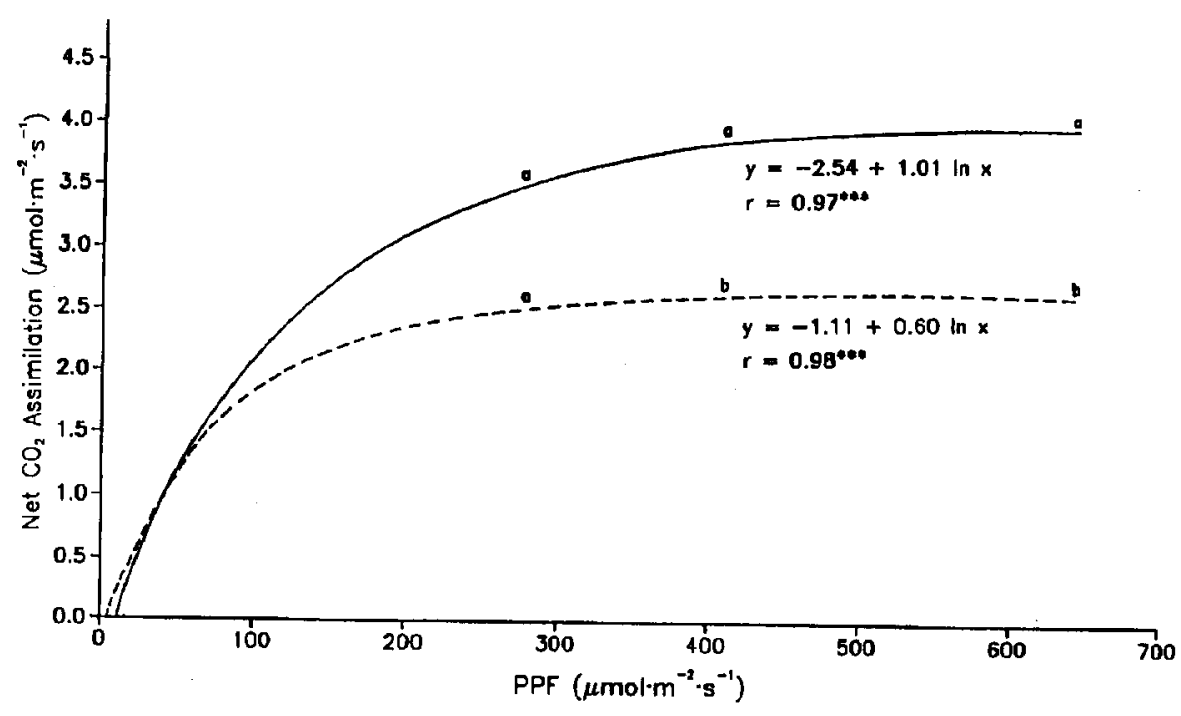

Fig. 3. Effect of photosynthetic photon flux (PPF) on net $\mathrm{CO}_{2}$ assimilation of leatherleaf fern fronds grown at a low-temperature treatment of 20 day/15C night $(-)$ or a high-temperature treatment of 30 day/ $25 \mathrm{C}$ night (---) and measured at 30C. Letters represent means of 10 replications, and different letters indicate significant differences for $t$ test comparisons at $P \leq 0.05$ within PPF for treatments. "'Significant at $\mathrm{P} \leq 0.001$. 